\title{
Treating MS after surviving PML: Discrete strategies for rescue, remission, and recovery patient 1
}

\author{
From the National Multiple Sclerosis Society Case Conference Proceedings
}

\author{
Nidhiben Anadani, MD, Megan Hyland, MD, MS, Roberto Alejandro Cruz, MD,* Robert Lisak, MD,* \\ Kathleen Costello, MS, ANP-BC, $\S$ Eugene O. Major, PhD,* Yasir Jassam, MBChB, MRCP(UK), \\ Ethan Meltzer, MD,* Thomas C. Varkey, MBA, * Matthew S. Parsons, PhD,* Andrew D. Goodman, MD,*

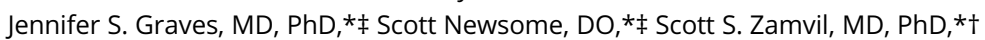 \\ Elliot M. Frohman, MD, PhD, *† and Teresa C. Frohman, MPAS, MSCS, PA-C*+£
}

Neurol Neuroimmunol Neuroinflamm 2021;8:e929. doi:10.1212/NXI.0000000000000929

\section{Case presentation}

A 38-year-old woman with MS receiving natalizumab presented to the neurology clinic with the complaint of a new neurologic symptom.

\section{Clinical course}

The patient had a 6-year history of clinically stable MS, albeit exhibiting radiographic progression despite strict adherence to daily subcutaneous glatiramer acetate (GA). Furthermore, on switching first to weekly IM interferon beta (IFN- $\beta$ ) 1a, she experienced clinical relapses and subsequently developed recalcitrant transaminitis while using three times weekly, subcutaneous IFN- $\beta$ 1b (figure 1).

Owing to continued disease activity and side effects from GA and IFN, she was switched to monthly IV natalizumab despite John Cunningham Polyomavirus antibody positivity (JCV $\mathrm{Ab}+$ ) with an $\mathrm{Ab}$ index 3.37-3.83. She remained clinically and radiographically stable from the inception of natalizumab with surveillance MRIs performed quarterly. However, after her 47th natalizumab infusion, she developed a coarse action and position tremor involving her right distal upper extremity. Brain MRI revealed a nonenhancing left thalamic T2 hyperintensity (figure 2, A and B).

Natalizumab was suspended while her physicians investigated the underlying etiology for her new clinical symptom and corresponding imaging abnormality. CSF analyses was noninflammatory and JCV DNA was undetectable by PCR. The initial diagnostic supposition was that the lesion was potentially on the basis of inflammatory demyelination, even in the absence
Correspondence

Dr. Frohman

Elliot.frohman@austin.utexas.edu

\section{RELATED ARTICLE}

Treating MS after surviving PML: Discrete strategies for rescue, remission, and recovery patient 2

Page e930

\footnotetext{
*National Multiple Sclerosis Society Case Conference Proceedings Faculty.

tEditor-in-Chief: Scott S. Zamvil, MD, PhD, Elliot M. Frohman, MD, PhD, and Teresa C. Frohman, MPAS, MSCS, PA-C.

¥Assistant Editor: Jennifer S. Graves, MD, PhD and Scott Newsome, DO.

SManaging Editors: Teresa C. Frohman, MPAS, MSCS, PA-C and Kathleen Costello, MS, ANP-BC.

From the University of Rochester (N.A.), NY. N. Anadani is now with Department of Neurology, University of Oklahoma Health Science Center; Department of Neurology (M.H., A.D.G.), University of Rochester, NY; Department of Neurology (R.A.C., E.M., T.C.V.), Dell Medical School at the University of Texas at Austin; Department of Neurology (R.L.), Wayne State University, Detroit, Ml; The National Multiple Sclerosis Society (K.C.), New York, NY; Laboratory of Molecular Medicine and Neuroscience (E.O.M.), Neurological Institute of Neurological Disorder and Stroke (Y.J.), Bethesda, MD. Y. Jassam is now with Department of Neurology, The University of Kansas Health System; Colangelo College of Business (T.C.V.), Grand Canyon University, Phoenix, AZ; Division of Microbiology and Immunology (M.S.P.), Yerkes National Primate Research Center, and Department of Pathology and Laboratory Medicine (M.S.P.), Emory University, Atlanta, GA; Department of Neurosciences (.S.G.), University of California at San Diego; Department of Neurology (S.N.), Johns Hopkins University School of Medicine, Baltimore, MD; Department of Neurology and Program in Immunology (S.S.Z.), University of California San Francisco; and Department of Neurology, Neurosurgery, and Ophthalmology (E.M.F., T.C.F.), Dell Medical School at the University of Texas at Austin.
}

Go to Neurology.org/NN for full disclosures. Funding information is provided at the end of the article.

The Article Processing Charge was funded by Neurology ${ }^{\circledR}$ Neuroimmunology \& Neuroinflammation.

This is an open access article distributed under the terms of the Creative Commons Attribution-NonCommercial-NoDerivatives License 4.0 (CC BY-NC-ND), which permits downloading and sharing the work provided it is properly cited. The work cannot be changed in any way or used commercially without permission from the journal. 
of gadolinium (Gd) enhancement. The patient was treated empirically with $1 \mathrm{~g}$ IV methylprednisolone daily for 3 doses without benefit.

Given concerns of her history of protracted natalizumab treatment and a high JCV antibody index, monthly serial MRIs were obtained (figure 2, C-G), which showed lesion progression, although JCV DNA was not detectable on serial CSF PCR analyses (4 in total).

Over time, the patient's tremor gradually worsened despite treatment with clonazepam and carbamazepine. Botulinum injection in combination with levetiracetam did mitigate the amplitude and frequency characteristics of the tremor such that the patient was able to recognize functional improvements. Notwithstanding such benefits on her tremor, she later exhibited features of dystonia that further interfered with her use of the right arm. Despite the unremarkable CSF analyses, clinical suspicion for progressive multifocal leukoencephalopathy (PML) remained high, although natalizumab was redosed once at 3 months to reduce the risk for potential rebound disease activity. ${ }^{1}$

\section{Differential diagnosis}

The patient's right upper extremity tremor corresponded with a new lesion that localized to the left ventral lateral posterior aspect of the thalamic nuclear complex-the target for the projections emanating from the right dentate nucleus of the cerebellum - which then projects to the left precentral gyrus, thereby providing right cerebellar influence on limb movements in the right arm.

At the time of presentation, the possibility of a new MS demyelinating lesion was considered high in the differential diagnosis. Demyelinating lesions due to MS are commonly localized in white matter (especially when using conventional MRI sequences), but focal lesions in the thalamus are also well documented. ${ }^{2}$ Typically, however, new demyelinating symptomatic lesions exhibit enhancement, and the absence of such in our patient compelled us to broaden the diagnostic differential.

Clinical manifestations of PML in MS are diverse and depend on the areas of the brain involved. Typically, brain MRI shows a T2 hyperintense/T1 hypointense lesion(s) with sharp margins, commonly involving subcortical white matter including extension into the U-fibers, although cortical involvement is often reported. Contrast enhancement is exceptional in HIV-associated PML, yet it is seen in about $40 \%$ of MS PML cases. ${ }^{3}$ Despite high sensitivity (>95\%) of CSF PCR for JCV in PML, JCV has infrequently remained undetectable in the CSF in cases where PML was confirmed by brain biopsy. ${ }^{4}$

\section{Final diagnosis}

As a precise diagnosis could not be made from the imaging and laboratory data, a biopsy of the lesion was performed 5 months after presentation. Histology demonstrated bizarre astrocytes, abundant CD68-positive macrophages, and nuclear changes suggestive of viral cytopathic effects. JCV DNA was detected at 9,964,282 copies $/ 10 \mu \mathrm{L}$ of extract confirming the diagnosis of PML.

\section{Discussion}

PML is a known complication of treatment with natalizumab in patients with MS with a history of previous exposure to JCV. ${ }^{5}$ Furthermore, risk of PML in patients who test positive for serum JCV Abs exponentially increases with a history of previous immunosuppression (e.g., cyclophosphamide, mitoxantrone, etc) and longer duration of continuous natalizumab therapy (e.g., >24 months). ${ }^{6}$ This does not include pulse steroids for treating relapses. This risk is further stratified by the quantitative index where a JCV Ab index $>1.5$ in patients with MS treated with natalizumab at 4-week intervals is associated with high risk of PML, although data suggest that extended interval dosing confers a lower risk of PML without compromising efficacy. ${ }^{8-10}$

Diagnostic confirmation of PML can often represent a formidable challenge, particularly given the heterogeneity in imaging characteristics. The conspicuity of PML lesion morphology in the context of HIV/AIDS can be distinctive from lesions evolving as a consequence of protracted immunosuppression in patients with autoimmune disorders. ${ }^{3}$ In HIV, PML lesions are typically hypointense and, on occasion, can exhibit enhancement, whereas such lesions in the context of patients with MS treated with natalizumab exhibit enhancement in $30 \%-40 \%$ of cases. ${ }^{3}$ Together, clinical presentation, radiologic findings, and presence of CSF JCV PCR DNA play important roles in PML diagnosis, although tissue biopsy also has a prominent and necessary role when other assessments fails to confirm the diagnosis.

Our case report presented herein illustrates that in spite of highly sensitive CSF assays for JCV DNA, such findings cannot adequately counter against the diagnosis of PML, particularly when a clinical syndrome in the setting of an atypical CNS lesion remains suspicious. In situations such as this, tissue biopsy is imperative and represents the gold standard.

Treatment of natalizumab-associated PML is complex. Plasmapheresis is an option, but one needs to consider the effect that the rapid removal of natalizumab may have in accelerating the development of the immune reconstitution inflammatory syndrome (IRIS). This is especially important because the clinical outcome can be worse with early PML-IRIS compared with late PML-IRIS. ${ }^{11}$ Corticosteroids may be used for PMLIRIS and have demonstrated benefit when used judiciously, although no randomized control studies are available.

The patient experienced clinical worsening with increased right sided weakness and dystonic tremor a few weeks after 


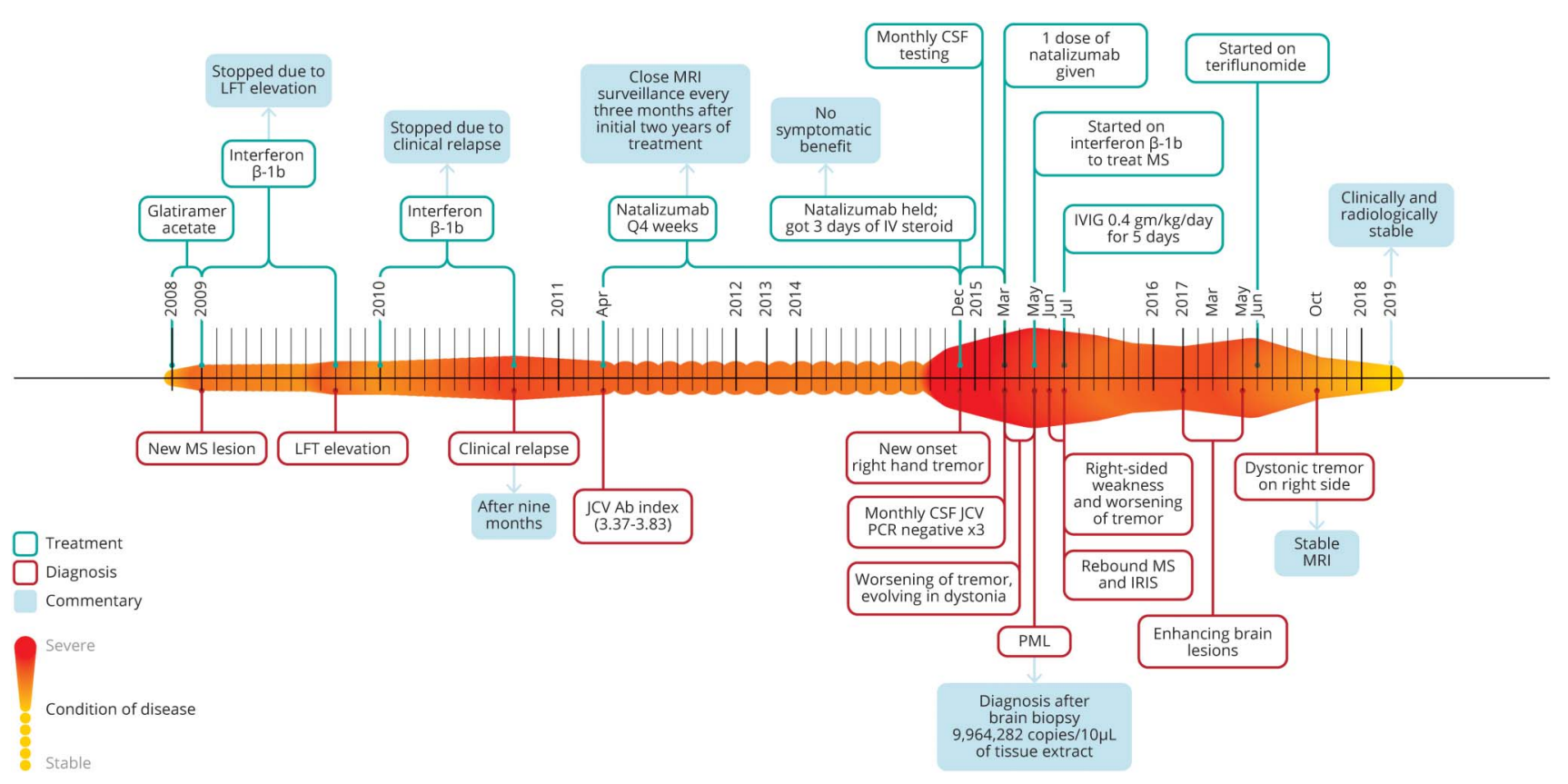

In this figure, we detail the condition of the patient over time. The longitudinal axis (left to right) depicts the condition of disease, where the smaller amplitude and lighter color indicates greater stability of MS. Alternately, the expanded amplitude of the colored heat map (above and below the horizontal linear axis over time) designates increased disease activity (whether on a clinical or paraclinical basis) or complications of the treatment of disease (e.g., PML). Four other fields of information are added either above or below the heat map and include information about treatments, diagnoses, commentaries adding contextual perspectives, and results from specific test assessments from each most relevant period of clinical decision-making. Each field is consistently color coded throughout as defined in the figure legend. IRIS = immune reconstitution inflammatory syndrome; IVIG = IV immunoglobulin; JCV Ab = John Cunningham Polyomavirus antibody; LFT = liver function test; PML = progressive multifocal leukoencephalopathy.

the biopsy. Postcontrast MRI performed at this time (27 weeks after symptom onset) showed nodular enhancement in the right frontal and parietal subcortical white matter, left frontal periventricular and precentral subcortical white matter, and in the left dorsolateral pons in the region of the left superior cerebellar peduncle (figure 3 , small arrow heads). Steroids were not used at this time because she had not tolerated them well on earlier administration. Instead, the

Figure 2 Evolution of the left thalamic lesion
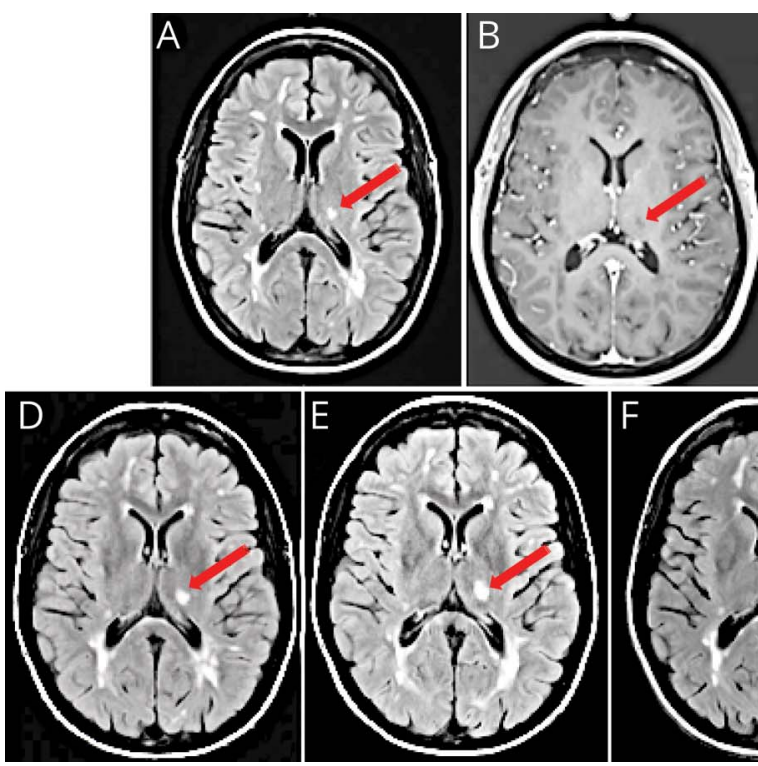

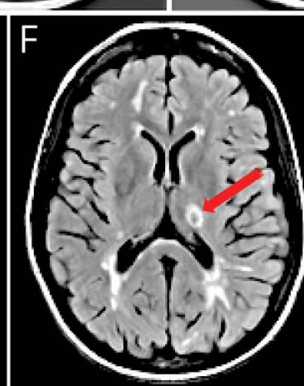

In (A), an axial T2 fluid-attenuated inversion recovery (FLAIR) image demonstrates a new hyperintense lesion localized to the left thalamus (red arrows), with periventricular and juxtacortical lesions typical of MS. In (B), an axial T1 postcontrast scan shows hypointensity of the left thalamic lesion without contrast enhancement. In (C-G), we present axial FLAIR images performed serially at 3, 7, 11, 16, and 20 weeks, respectively, after the inception of the right upper extremity tremor. Over this period, the lesion has slightly increased in size, and in (F), the lesion takes on a ring configuration with central hypointensity (red arrows). This lesion failed to exhibit any evidence of contrast enhancement over the period of surveillance imaging. 

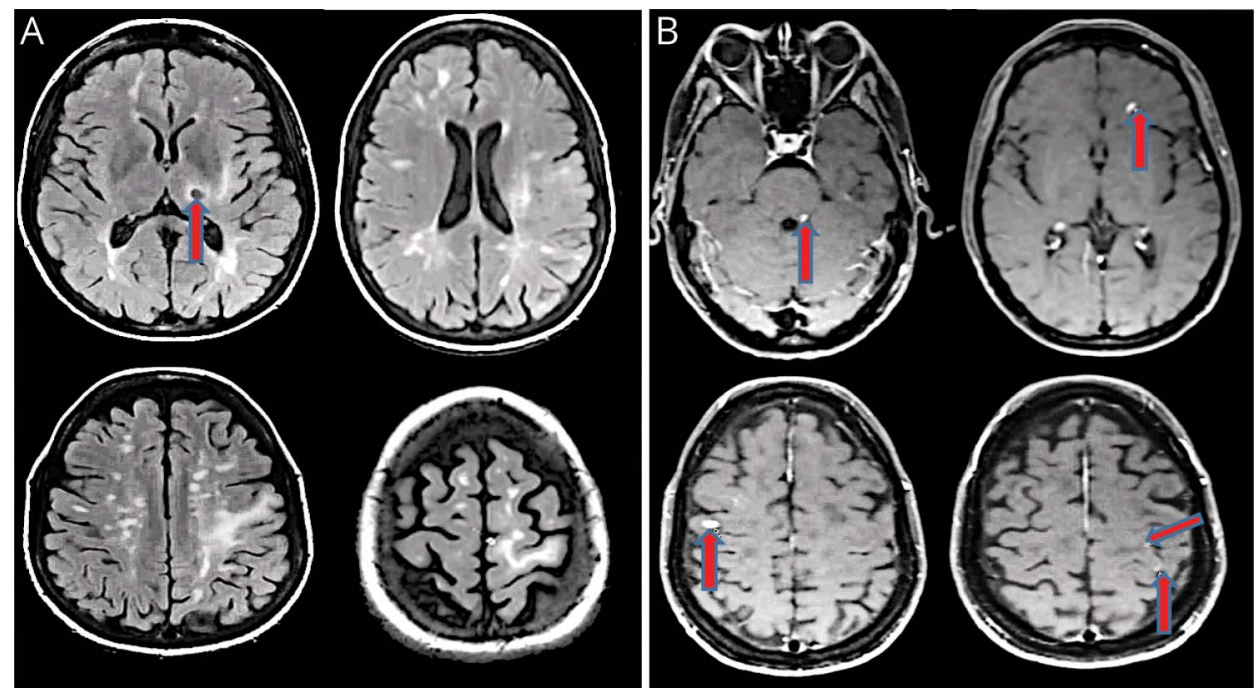

In (A), we present axial fluid-attenuated inversion recovery images revealing disseminated lesions characteristic for inflammatory demyelination in the periventribular zones, in the centrum semiovale, in the corona radiata, and in the cortex and juxtacortical zones, in addition to the previously identified left thalamic lesion, here exhibiting a ring configuration with central hypointensity (red arrow). In (B), we present axial T1 postcontrast images showing various nodular enhancing lesions in left dorsolateral pons and bilateral frontal lobes and patchy punctate enhancements in left frontal and parietal white matter (red arrows).

patient was treated with $0.4 \mathrm{~g} / \mathrm{kg} / \mathrm{d}$ IV immunoglobulin for a total of 5 days, after which she exhibited further improvement in her symptoms.

Unfortunately, there are limited data in the literature regarding disease-modifying therapy (DMT) options in such patients who have been diagnosed with natalizumabassociated PML. However, one small case series suggests that INF- $\beta$ and GA, as well as dimethyl fumarate and fingolimod, seem to be safe in post-PML patients, although longterm safety data are lacking. ${ }^{12,13}$ There are a few case reports that describe utilization of rituximab in post-PML patients. ${ }^{14}$

In the case reported herein, there was significant concern that use of an immunosuppressive DMT might provoke recrudescence of PML, thereby compromising neurologic recovery. As such, the patient was started on immunomodulatory therapy, in spite of its previous incomplete effectiveness for treating her MS. Specifically, IFN- $\beta$ lb was selected over daily subcutaneous GA because of presumed more rapid onset of action with IFN therapy and the patient preference regarding tolerability with fewer injections.

The patient tolerated IFN- $\beta$ 1b without side effects or radiologic activity for 19 months. However, she then developed a left parietal lobe T2 hyperintensity that demonstrated incomplete peripheral Gd-enhancement, most compatible with an active MS lesion. Repeat MRIs after 2 and 4 months showed additional new enhancing lesions, although the previously identified left thalamic lesion and the subcortical white matter changes extending from the left thalamus to prefrontal cortex seemed less conspicuous. IFN- $\beta$ neutralizing antibodies were not detected.

Once clinical stabilization was achieved, attention then shifted to the intensification of the patient's MS DMT, with the goal to use an agent with properties capable of achieving a durable remission while also conferring a low risk of PML recrudescence. For these reasons, once-daily oral teriflunomide was identified as an acceptable next step in the patient's treatment course (figure 1). This agent targets the biosynthetic enzyme, dihydro-orotate dehydrogenase, thereby inhibiting the de novo pyrimidine synthesis pathway (principally used by rapidly dividing cells such as $\mathrm{T}$ and B lymphocytes and for virion replication).

To date, our patient has remained clinically and radiologically stable for more than 2 years after the treatment transition to teriflunomide. Despite the achievement of this period of remission in our patient's disease activity, careful and systematic clinical and paraclinical surveillance investigations will be imperative. Until evidence-based data sufficient to provide treatment guidelines become available, the management of MS after the development and survival of PML must be formulated on a case-by-case basis.

\section{Acknowledgment}

The authors thank medical illustrators Mr. Jason Ooi and Dr. Matthew Parsons for their creation of the chronological heat map (figure 1).

\section{Study funding}

The National Multiple Sclerosis Society Case Conference Proceedings is a peer review publishing initiative from the monthly "Diagnostic and Treatment Challenges in MS and Neuroimmunology Webinars"; sponsored by the National Multiple Sclerosis Society Fellowship Training Program.

\section{Disclosure}

N. Anadani: clinical fellowship funded by National MS Society. M. Hyland: research support from Biogen, PCORI. R.A. 
Cruz: clinical fellowship funded by National MS Society. R. Lisak serves as a member of the Editorial Board of Clinical Neuropharmacology; he serves on the Medical Advisory Committee of the Myasthenia Gravis Foundation of America and on its Grants Review Committee, on the Clinical Advisory Committee of the GBS/ CIDP Foundation, International and its Research/Grants Committee and its Committee on Centers of Excellence, the Board of Trustees of the Michigan Chapter of the National Multiple Sclerosis Society and is Health Care Advisory Committee and on the Board of Trustees of the DMC Foundation; he has served as a consultant for Argenx, Novartis, Janssen, GLG Consulting, Guidepoint Consulting, Third Bridge Consulting, and Globe Life Sciences; he chaired the adjudication committee for a medDay Pharmaceutical clinical trial; he receives research funding (with salary support paid directly to Wayne State University) from NIH, Argnex, UCB Ra Pharmaceuticals and Alexion; and he has received royalties from Wiley-Blackwell (International Neurology) and Oxford University Press (Neuroimmunology). K. Costello has nothing to disclose. E.O. Major: PML Adjudication Committees for Takeda/Millennium Pharma; Roche/Genentech, GSK, and Shire; consult PolpharmaBiologics, S.A. Y. Jassam: past member of the board of governors of the consortium of multiple sclerosis center (CMSC): 2015-2019. BIOGEN post-ECTRIMS advisory board (no consultation fees accepted); current contracted research sponsorship relations: present support: co-investigator: Roche Protocol \#WA21493/ACT44 (2017-2021), Roche Protocol \#WA21093 (2017-2022), Roche Protocol \#WA25046 (2017-2021), Roche Protocol \#NB40900 (formerly Chugai Pharmaceutical Protocol \#SA-309JG) (2017-2021), MedImmune LLC Protocol \#CDIA-MEDI-5511155 (2017-2020), Novartic Protocol \#CFTY720D2403 (2017-2020), Genzyme Protocol \#LPS13649 (2017-2020), MedDay Protocol \#MD1003CT2016-01MS-SPI2 (2017-2020), Mallinckrodt Protocol \#MNK14274069 (2017-2020), Actelion Protocol \#AC-058B302 (2017-2020), Alexion Pharmaceuticals Protocol \#ECU-NMO-302 (2017-2020), Novartis Protocol \#COMB157G2399 (2018-2025), TG Therapeutics Protocol \#TG1101-RMS303 (2020-2023), Alexion Pharmaceuticals Protocol \#ALXN1210-NMO-307 (2020-2024), Roche Protocol \#WA40404 (2020-2028); past support: primary investigator: FLUENT study, Novartis pharmaceuticals; co-investigator: Teva Protocol \#MS-LAQ-301E (May 2010-2018); Teva Pharmaceuticals USA Protocol \#TV5600-CNS-20006015-2017, Novartis Protocol \#CFTY720D2312 (2017-2018), Genentech Protocol \#MN30035 (2017-2019), Novartis Protocol \#COMB157G2301 (2017-2019), Alexion Pharmaceuticals Protocol \#ECU-NMO-301 (2017-2020), TG Therapeutics Protocol \#TG1101-RMS301 (2017-2020). E. Meltzer served as a consultant for Genzyme and received honoraria from Novartis. T.C. Varkey and M.S. Parsons have nothing to disclose. A.D. Goodman received personal compensation for consulting from Teva and Adamas; received research support from Biogen, Genentech-Roche, Sanofi-Genzyme, and Teva. Unrelated to the current work, J.S. Graves over the past year has grant/contract research support from the National MS Society, Biogen, and Octave Biosciences; she serves on a steering committee for a trial supported by Novartis; she has received honoraria for a non-promotional, educational activity for SanofiGenzyme; she has received speaker fees from Alexion and BMS and

served on an advisory board for Genentech. S. Newsome has received consultant fees for scientific advisory boards from Biogen, Genentech, Celgene, EMD Serono, Novartis, Greenwich Biosciences, is an advisor for Autobahn Therapeutics and BioIncept, a clinical adjudication committee member for a MedDay Pharmaceuticals clinical trial and has received research funding (paid directly to institution) from Biogen, Novartis, Genentech, National MS Society, Department of Defense, and Patient Centered Outcomes Institute. S.S. Zamvil is Deputy Editor of Neurology: Neuroimmunology \& Neuroinflammation and is an Associate Editor for Frontiers in Immunology and Frontiers in Neurology; he serves on the Advisory Committee for the American Congress on Treatment and Research in Multiple Sclerosis (ACTRIMS) and is a standing member of the research grant review committee for the National Multiple Sclerosis Society (NMSS); he has served on the Editorial Board of the Journal of Clinical Investigation, The Journal of Immunology, and The Journal of Neurological Sciences, and has been a charter member of the grant review committee for the NIH Clinical Neuroimmunology and Brain Tumors (CNBT); he has served, or serves, as a consultant and received honoraria from Alexion, BiogenIdec, EMD-Serono, Genzyme, Novartis, Roche/Genentech, and Teva Pharmaceuticals Inc., and has served on Data Safety Monitoring Boards for Lilly, BioMS, Teva and Opexa Therapeutics; currently, S.S. Zamvil receives research grant support from the NIH, NMSS, Weill Institute, Race to Erase MS and the Maisin Foundation. E.M. Frohman has received speaker and consulting fees from Novartis, Genzyme, Biogen and Janssen. T.C. Frohman has received consulting honorarium from Genzyme. Go to Neurology. org/NN for full disclosures.

\section{Publication history}

Received by Neurology: Neuroimmunology \& Neuroinflammation October 6, 2020. Accepted in final form October 21, 2020.

Appendix Authors

\begin{tabular}{lll}
\hline Name & Location & Contribution \\
\hline $\begin{array}{l}\text { Nidhiben } \\
\text { Anadani, MD }\end{array}$ & $\begin{array}{l}\text { Neuroimmunology/ } \\
\text { Multiple Sclerosis fellow, } \\
\text { University of Rochester, } \\
\text { NY; Department of } \\
\text { Neurology, University of } \\
\text { Oklahoma Health Science } \\
\text { Center (Current) }\end{array}$ & $\begin{array}{l}\text { Conception and critical } \\
\text { revision of the manuscript } \\
\text { for intellectual content }\end{array}$ \\
\hline $\begin{array}{l}\text { Megan } \\
\text { Myland, MD, }\end{array}$ & $\begin{array}{l}\text { Department of Neurology, } \\
\text { University of Rochester, }\end{array}$ & $\begin{array}{l}\text { Conception and critical } \\
\text { revision of the manuscript } \\
\text { for intellectual content }\end{array}$ \\
\hline $\begin{array}{l}\text { Roberto A. } \\
\text { Cruz, MD }\end{array}$ & $\begin{array}{l}\text { MS \& Neuroimmunology } \\
\text { CTR; Department of }\end{array}$ & $\begin{array}{l}\text { Critical revision of the } \\
\text { manuscript for intellectual } \\
\text { content }\end{array}$ \\
& $\begin{array}{l}\text { Neurology, Dell Medical } \\
\text { School, University of Texas } \\
\text { at Austin }\end{array}$ & \\
\hline Robert Lisak, & $\begin{array}{l}\text { Department of Neurology, } \\
\text { MD }\end{array}$ & $\begin{array}{l}\text { Conception and critical } \\
\text { revision of the manuscript } \\
\text { for intellectual content }\end{array}$ \\
\hline $\begin{array}{l}\text { Katroit Michigan } \\
\text { Kathleen } \\
\text { ANP-BC }\end{array}$ & $\begin{array}{l}\text { The National Multiple } \\
\text { Sclerosis Society, New } \\
\text { York, NY }\end{array}$ & $\begin{array}{l}\text { Critical revision of the } \\
\text { manuscript for intellectual } \\
\text { content }\end{array}$ \\
\hline
\end{tabular}


Appendix (continued)

\begin{tabular}{|c|c|c|}
\hline Name & Location & Contribution \\
\hline $\begin{array}{l}\text { Eugene O. } \\
\text { Major, PhD }\end{array}$ & $\begin{array}{l}\text { Laboratory of Molecular } \\
\text { Medicine and } \\
\text { Neuroscience, } \\
\text { Neurological Institute of } \\
\text { Neurological Disorder and } \\
\text { Stroke, Bethesda, MD }\end{array}$ & $\begin{array}{l}\text { Conception and critical } \\
\text { revision of the manuscript } \\
\text { for intellectual content }\end{array}$ \\
\hline $\begin{array}{l}\text { Yasir Jassam, } \\
\text { MBChB, } \\
\text { MRCP(UK) }\end{array}$ & $\begin{array}{l}\text { Neurological Institute of } \\
\text { Neurological Disorder and } \\
\text { Stroke, Bethesda, MD; } \\
\text { Department of Neurology, } \\
\text { The University of Kansas } \\
\text { Health System (current) }\end{array}$ & $\begin{array}{l}\text { Conception and critical } \\
\text { revision of the manuscript } \\
\text { for intellectual content }\end{array}$ \\
\hline $\begin{array}{l}\text { Ethan } \\
\text { Meltzer, MD }\end{array}$ & $\begin{array}{l}\text { Department of Neurology, } \\
\text { Dell Medical School at the } \\
\text { University of Texas at } \\
\text { Austin, Austin, TX }\end{array}$ & $\begin{array}{l}\text { Critical revision of the } \\
\text { manuscript for intellectual } \\
\text { content }\end{array}$ \\
\hline $\begin{array}{l}\text { Thomas C. } \\
\text { Varkey, MBA }\end{array}$ & $\begin{array}{l}\text { Department of Neurology, } \\
\text { Dell Medical School at the } \\
\text { University of Texas at } \\
\text { Austin and 3rd Year } \\
\text { Medical Student at Dell } \\
\text { Medical School, Colangelo } \\
\text { College of Business, Grand } \\
\text { Canyon University, } \\
\text { Phoenix, AZ }\end{array}$ & $\begin{array}{l}\text { Critical revision of the } \\
\text { manuscript for intellectual } \\
\text { content }\end{array}$ \\
\hline $\begin{array}{l}\text { Matthew S. } \\
\text { Parsons, PhD }\end{array}$ & $\begin{array}{l}\text { Division of Microbiology } \\
\text { and Immunology, Yerkes } \\
\text { National Primate Research } \\
\text { Center, Department of } \\
\text { Pathology and Laboratory } \\
\text { Medicine, Emory } \\
\text { University }\end{array}$ & $\begin{array}{l}\text { Conception and critical } \\
\text { revision of the manuscript } \\
\text { for intellectual content }\end{array}$ \\
\hline $\begin{array}{l}\text { Andrew D. } \\
\text { Goodman, } \\
\text { MD }\end{array}$ & $\begin{array}{l}\text { Department of neurology, } \\
\text { University of Rochester, } \\
\text { NY }\end{array}$ & $\begin{array}{l}\text { Conception and critical } \\
\text { revision of the manuscript } \\
\text { for intellectual content }\end{array}$ \\
\hline $\begin{array}{l}\text { Jennifer S. } \\
\text { Graves, MD, } \\
\text { PhD }\end{array}$ & $\begin{array}{l}\text { Department of } \\
\text { Neuroscience, UC San } \\
\text { Diego }\end{array}$ & $\begin{array}{l}\text { Critical revision of the } \\
\text { manuscript for intellectual } \\
\text { content }\end{array}$ \\
\hline $\begin{array}{l}\text { Scott } \\
\text { Newsome, } \\
\text { DO }\end{array}$ & $\begin{array}{l}\text { Department of neurology, } \\
\text { Johns Hopkins University } \\
\text { School of Medicine, } \\
\text { Baltimore, MD }\end{array}$ & $\begin{array}{l}\text { Critical revision of the } \\
\text { manuscript for intellectual } \\
\text { content }\end{array}$ \\
\hline $\begin{array}{l}\text { Scott S. } \\
\text { Zamvil, MD, } \\
\text { PhD }\end{array}$ & $\begin{array}{l}\text { Department of neurology } \\
\& \text { Program in } \\
\text { Immunology, University of } \\
\text { California, San Francisco }\end{array}$ & $\begin{array}{l}\text { Conception and critical } \\
\text { revision of the manuscript } \\
\text { for intellectual content }\end{array}$ \\
\hline
\end{tabular}

Appendix (continued)

\begin{tabular}{|c|c|c|}
\hline Name & Location & Contribution \\
\hline $\begin{array}{l}\text { Elliot M. } \\
\text { Frohman, } \\
\text { MD, PhD }\end{array}$ & $\begin{array}{l}\text { MS \& Neuroimmunology } \\
\text { CTR; Departments of } \\
\text { Neurology, Neurosurgery } \\
\text { \& Ophthalmology, Dell } \\
\text { medical School, University } \\
\text { of Texas at Austin }\end{array}$ & $\begin{array}{l}\text { Conception and critical } \\
\text { revision of the manuscript } \\
\text { for intellectual content; } \\
\text { final revision, size } \\
\text { reduction, and critical } \\
\text { review with T.C. Frohman } \\
\text { and S.S. Zamvil }\end{array}$ \\
\hline $\begin{array}{l}\text { Teresa C. } \\
\text { Frohman, } \\
\text { MPAS, MSCS, } \\
\text { PA-C }\end{array}$ & $\begin{array}{l}\text { MS \& Neuroimmunology } \\
\text { CTR; Departments of } \\
\text { Neurology, Neurosurgery } \\
\text { \& Ophthalmology, Dell } \\
\text { medical School, University } \\
\text { of Texas at Austin }\end{array}$ & $\begin{array}{l}\text { Conception and critical } \\
\text { revision of the manuscript } \\
\text { for intellectual content; final } \\
\text { revision, organizational } \\
\text { review, reduction in the } \\
\text { size of the paper, and } \\
\text { elimination of redundancies }\end{array}$ \\
\hline
\end{tabular}

\section{References}

1. Prosperini L, Kinkel RP, Miravalle AA, Iaffaldano P, Fantaccini S. Post-natalizumab disease reactivation in multiple sclerosis: systematic review and meta-analysis. Ther Adv Neurol Disord Epub 2019 Mar 29.

2. Minagar A, Barnett $\mathrm{MH}$, Benedict R, et al. The thalamus and multiple sclerosis Modern views on pathologic, imaging, and clinical aspects. Neurology 2013;80:210-219.

3. Yousry TA, Pelletier D, Cadavid D, et al. Magnetic resonance imaging pattern in natalizumabassociated progressive multifocal leucoencephalopathy, Ann Neurol 2012;72:779-787.

4. Berger J, Aksamit AJ, Clifford DB, et al. PML diagnostic criteria: consensus statement from the AAN Neuroinfectious Disease Section. Neurology 2013;80:1430-1438.

5. Bloomgren G, Richman S, Hotermans C, et al. Risk of natalizumab-associated progressive multifocal leukoencephalopathy. N Engl J Med 2012;366:1870-1880.

6. Zhovtis Ryerson L, Foley J, Chang IH, et al. Risk of natalizumab-associated PML in patients with MS is reduced with extended interval dosing. Neurology 2019;93;e1452-e1462.

7. Ho PR, Koendgen H, Campbell N, Haddock B, Richman S, Chang I. Risk of natalizumabassociated progressive multifocal leukoencephalopathy in patients with multiple sclerosis: a retrospective analysis of data from four clinical studies. Lancet Neurol 2017;16:925-933.

8. Zhovtis Ryerson L, Frohman TC, Foley J, et al. Extended interval dosing of natalizumab in multiple sclerosis. J Neurol Neurosurg Psychiatry 2016;87:885-889. doi: 10. 1136/jnnp-2015-312940.

9. Clerico M, De Mercanti SF, Signori A, et al. Extending the interval of natalizumab dosing: is efficacy preserved? Neurotherapeutics 2020;17:200-207. doi: 10.1007/ s13311-019-00776-7.

10. Ryerson LZ, Foley J, Chang I, et al. Risk of natalizumab-associated PML in patients with MS is reduced with extended interval dosing. Neurology 2019;93:e1452-e1462. doi: 10.1212 WNL.0000000000008243.

11. Tan K, Roda R, Ostrow L, McArthur J, Nath A. PML-IRIS in patients with HIV infection. Clinical manifestations and treatment with steroids. Neurology 2009;72:1458-1464.

12. Maillart E, Vidal JS, Brassat D, et al. Natalizumab-PML survivors with subsequent MS treatment: clinico-radiologic outcome. Neurol Neuroimmunol Neuroinflamm 2017;4:e346.

13. Maillart E, Louapre C, Lubetzki C, Papeix C. Fingolimod to treat severe multiple sclerosis after natalizumab-associated progressive multifocal leukoencephalopathy: a valid option? Mult Scler 2014;20:505-509.

14. Hoepner R, Faissner S, Ellrichmann G, Schneider R, Gold R. Rituximab post progressive multifocal leukoencephalopathy: a feasible therapeutic option in selected cases. Ther Adv Neurol Disord 2014;7:289-291. 


\section{Neurology \\ Neuroimmunology \& Neuroinflammation}

Treating MS after surviving PML: Discrete strategies for rescue, remission, and recovery patient 1: From the National Multiple Sclerosis Society Case Conference Proceedings

Nidhiben Anadani, Megan Hyland, Roberto Alejandro Cruz, et al.

Neurol Neuroimmunol Neuroinflamm 2021;8;

DOI 10.1212/NXI.0000000000000929

This information is current as of December 15, 2020

\begin{abstract}
Updated Information \&
Services

References

Subspecialty Collections

Permissions \& Licensing

Reprints

including high resolution figures, can be found at:

http://nn.neurology.org/content/8/1/e929.full.html

This article cites 13 articles, 2 of which you can access for free at: http://nn.neurology.org/content/8/1/e929.full.html\#\#ref-list-1

This article, along with others on similar topics, appears in the following collection(s):

All Immunology

http://nn.neurology.org//cgi/collection/all_immunology

Multiple sclerosis

http://nn.neurology.org//cgi/collection/multiple_sclerosis

Information about reproducing this article in parts (figures,tables) or in its entirety can be found online at:

http://nn.neurology.org/misc/about.xhtml\#permissions

Information about ordering reprints can be found online:

http://nn.neurology.org/misc/addir.xhtml\#reprintsus
\end{abstract}

Neurol Neuroimmunol Neuroinflamm is an official journal of the American Academy of Neurology.

Published since April 2014, it is an open-access, online-only, continuous publication journal. Copyright

Copyright $\odot 2020$ The Author(s). Published by Wolters Kluwer Health, Inc. on behalf of the American

Academy of Neurology.. All rights reserved. Online ISSN: 2332-7812.

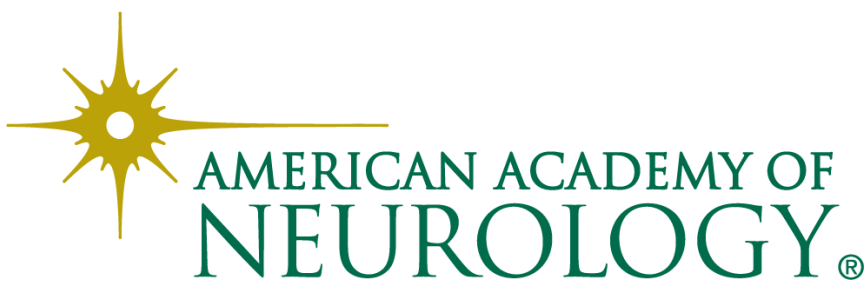

